\title{
Comparative Assessment of Infiltration, Runoff and Erosion of Sprinkler Irrigated Soils
}

\author{
Francisco L. Santos; João L. Reis; Olga C. Martins; Nádia L. Castanheira; Ricardo P. Serralheiro \\ Department of Rural Engineering, University of Évora, Évora, Portugal; e-mail of corresponding author: fls@uevora.pt
}

(Received 14 January 2003; accepted in revised form 10 July 2003; published online 4 September 2003)

\begin{abstract}
The impacts of sprinkler irrigation on infiltration, runoff and sediment loss of ten representative soils of Southern Portugal were assessed by laboratory sprinkler irrigation simulation tests. All soils showed very low permeability to applied water. The mechanical impact of water droplets enhanced soil dispersion and further lowered their infiltration capacity, particularly for high clay plus silt content soils that showed the poorest results. As a consequence, high runoff and sediment losses were also measured, primarily with the first irrigation. More moderate losses were observed thereafter. Soils with higher sand particle size fractions better absorbed the energy impact of droplets and showed higher infiltration rates and lower runoff and sediment losses. Polyacrylamide (PAM) applied to the soils through the irrigation water acted as a binding and settling agent to increase soils aggregate stability and infiltration and reduce runoff and sediment losses. Slope increase, from 2.5 to $5 \%$, decreased overall soils infiltration by $7 \%$ and increased runoff and sediment losses by 10 and $27 \%$, respectively. Exposed to the same change in slope, PAM application boosted overall infiltration of treated soils to a $24 \%$ difference and increased runoff by only $10 \%$. It had a less positive effect on sediment loss, the 5\% slope being responsible for a $52 \%$ increase. In agreement with this the tests showed that, compared to the control, exposure of PAM-treated soil on 2.5 and $5 \%$ slopes enhanced overall infiltration to 457 and $642 \%$ respectively, reduced runoff by $25 \%$ on both cases and lessened sediment loss by 39 and $27 \%$. The demonstrated ability of PAM to influence surface soil conditions of specific soils can be used to reduce the environmental risks associated with the intensive use of sprinkler irrigation in Southern Portugal. It offers a safe, practical and non-intrusive management alternative to current costly, labour- and energy-intensive practices of increasing the number of machine turns and building storage basins to control runoff and soil erosion.
\end{abstract}

(C) 2003 Silsoe Research Institute. All rights reserved

Published by Elsevier Ltd

\section{Introduction}

In a relatively dry and almost treeless Mediterranean region, the distinctive characteristic of the farming practices in Southern Portugal has been its dry farming on a landscape of rolling hills, dotted by flatter irrigated alluvial soils. With farmers adopting modern irrigation technologies, primarily sprinklers and centre-pivots, and expanding their agricultural production into the undulating fields, this scenery is rapidly changing. The adoption of irrigation renders substantial net margins to farmers but also introduces the potential for severe soil problems to the newly irrigated land, unless ameliorative measures are taken. The high kinetic energy of the applied water impacting on the soil surface compacts soil and detaches soil particles, causing pore blockage and soil infiltration rate reduction. The associated water application, with rates often exceeding the hydraulic conductivity of soils, generates runoff, sediment loss and soil erosion. Adding to the concerns, a new irrigation scheme is under construction and will add a further 110000 sprinkler and centre-pivot irrigated hectares to the area (Serralheiro et al., 1997), at the same time that increasing evidence is showing that subtle changes are also taking place in the flatter alluvial lands, where the new sprinkler irrigation technologies are gradually replacing the more traditional surface irrigation (INE, 2001).

With highly erodible soils supporting most of the newly irrigated land (Shainberg et al., 1991; Ferreira 
et al., 1994; Santos et al., 1998), the sustainability of the irrigated agriculture in Southern Portugal is at serious risk. One of the strategies used to control surface runoff and minimise erosion has been to increase the speed of the moving sprinkler systems to apply small amounts of water, compatible with the low soil infiltration rates (Slack \& Larson, 1981). However, the increasing number of machine turns and its associated labour and energy costs penalise the option, making it unattractive to farmers. Another strategy that has shown some applicability to halt surface runoff is the construction of storage basins in the furrows between ridges (Kincaid et al., 1990; Hasheminia, 1994). These increase superficial storage and the opportunity time for water to infiltrate, thereby reducing down slope flow and runoff. Cost and scheduling, as it requires a special implement to build the bunds and time set aside to do so, make it unattractive and too intrusive to farmers. Water droplets have also been shown (Kincaid et al., 1990) to gradually degrade bunds and ridge sides of the storage basins, allowing water, with the breakdown of bunds, to cascade down the slope, worsening runoff and sediment detachment. Best sprinkler irrigation management practices for these soils require predicting their infiltration, runoff and sediment losses and prescribing conservation practices than can be readily used without being too intrusive, too costly or labour intensive. High molecular weight anionic water-soluble polyacrylamide (PAM) applied to the soil at a rate of $10 \mathrm{mg} l^{-1}$ has been reported to provide an answer to such needs (Sojka et al., 2001) while accounting for a variety of beneficial soil amendment properties, including minimisation of water runoff through increased infiltration, stabilisation of soil aggregates and erosion reduction (Sojka et al., 1998; Aase et al., 1998; Bjorneberg \& Aase, 2000). Santos and Serralheiro (2000) and Santos et al. (2001) have described similar amendment properties and conservation efficacy when $10 \mathrm{mg} l^{-1}$ PAM was applied to some of the soils under scrutiny. Evaluation and assessment of the impacts of irrigation and conservation amendments on the behaviour of soils may be accomplished in two ways: (a) by collecting field data on all soil types over a long period of time or (b) by predicting their future behaviour through laboratory tests simulating field conditions, and collecting data. The latter approach can be more cost effective, practical and environmentally safer.

The objective of this paper is to summarise results of laboratory tests on infiltration, runoff and sediment loss conducted under a sprinkler irrigation simulator in ten different but representative soil series of Southern Portugal, to assist in predicting their behaviour when exposed to field sprinkler irrigations. As infiltration is governed by soil physical properties and the time and amount of water applied whereas runoff and sediment loss are controlled by the physical impact of water droplets and sequences of wet and dry (Shainberg \& Singer, 1985; Shainberg et al., 1991), each soil was irrigated three times for $30 \mathrm{~min}$ periods at weekly intervals with drainage and runoff samples taken every 5 min during the irrigation. Polyacrylamide (PAM) at a rate of $1 \mathrm{~kg} \mathrm{ha}^{-1}\left(10 \mathrm{mg} l^{-1}\right)$ was also applied to the soils through the irrigation water, to evaluate its effectiveness in promoting their aggregate stability, infiltration and sediment flocculation and to provide insights into its merits when applied to soils via field sprinkler irrigation systems. To help capture the impact of the rolling landscape into the objectives of the study, two distinct slopes, 2.5 and $5 \%$, were taken into account and their effects on irrigation examined.

\section{Materials and methods}

Ten soil series of Southern Portugal were the subject of laboratory tests under a sprinkler simulator similar in design to that described by Morin et al. (1967). Field collection and treatment of the soil samples as well as the sampling locations, morphologic characteristics and geographic location coordinates are found in Silva (1999). Soil particle size fractions and classifications are presented in Table 1. A more complete description and characterisation are covered elsewhere (Cardoso, 1965; CNROA, 1987). Soil series Bpc, Bvc, Bp and Cb represent Vertisol soils with high clay content in the profile and well-defined prismatic structure in the A- and B-horizons. Periodic expansion and contraction of the montmorillonite clay found at the upper horizon cause the frequently observed cracking and swelling of soil surface. Soil series Pmg is among the ten the only true Mediterranean soil. With an illuvial B-horizon originated from clay illuviation off the A-horizon, its main characteristic under irrigation is a rapidly permeable A-horizon overlying a B-horizon of very low permeability. Due to the soil conditions at the surface (texture, structure and low aggregate stability), irrigation often induces sediment detachment and movement at the soil surface, causing soil pore blockage, crusting and declining infiltration rates (Santos \& Serralheiro, 2000). Soil series $A 1$ and $A 2$ are the typical alluvial soils found on the flat lands dotting the rolling landscape of Southern Portugal. Owing to the randomness of sediment deposition along riverbanks, their particle size fractions tend to be highly variable. Considered prime soils for surface irrigation, their often relatively high proportions of silt and sand in the upper horizon may cause infiltration and runoff problems, leading to sediment loss and erosion (Santos et al., 2001; 
Table 1

Particle size fraction and classification for the ten sprinkler irrigated soil series

\begin{tabular}{|c|c|c|c|c|c|}
\hline \multirow[t]{2}{*}{ Portuguese soil classification } & \multirow[t]{2}{*}{ International (FAO) soil classification } & \multicolumn{4}{|c|}{ Particle size fraction, $\%$} \\
\hline & & Sand & Fine sand & Silt & Clay \\
\hline $\mathrm{Bvc}$ & Vertisol calcic & $7 \cdot 2$ & $11 \cdot 2$ & $37 \cdot 4$ & $44 \cdot 2$ \\
\hline $\mathrm{Bpc}$ & Vertisol calcic & $12 \cdot 3$ & $15 \cdot 4$ & $20 \cdot 9$ & 51.4 \\
\hline $\mathrm{Bp}$ & Vertisol eutric & $21 \cdot 9$ & $20 \cdot 6$ & $18 \cdot 7$ & 38.9 \\
\hline $\mathrm{Cb}$ & Vertisol eutric & $21 \cdot 8$ & $26 \cdot 4$ & $15 \cdot 3$ & $36 \cdot 5$ \\
\hline Pmg & Luvisol & $56 \cdot 4$ & $19 \cdot 9$ & $9 \cdot 7$ & $16 \cdot 4$ \\
\hline A1 & Fluvisol dystric & $51 \cdot 2$ & $14 \cdot 8$ & $17 \cdot 6$ & $14 \cdot 0$ \\
\hline A2 & Fluvisol dystric & 41.9 & $18 \cdot 1$ & $24 \cdot 7$ & $15 \cdot 4$ \\
\hline $\mathrm{Pg}$ & Cambisol dystric & $50 \cdot 8$ & $29 \cdot 3$ & $11 \cdot 0$ & $11 \cdot 4$ \\
\hline Ppg & Cambisol dystric & $55 \cdot 3$ & 21.9 & $12 \cdot 1$ & $10 \cdot 7$ \\
\hline $\mathrm{Vt}$ & Cambisol dystric & $33 \cdot 3$ & $28 \cdot 3$ & $27 \cdot 0$ & $8 \cdot 9$ \\
\hline
\end{tabular}

FAO, Food and Agriculture Organisation.

Ferreira et al., 1994; Shainberg et al., 1991). Soil series $\mathrm{Pg}$, Ppg and Vt belong to a class of poorly mature soils with a thin sandy to sandy-loam A-horizon overlaying the C-horizon. Shallow depths and the coarseness of A-horizon often discourage their use for irrigation.

After field collection, each soil sample was air dried, sieved to a mesh of $3.5 \mathrm{~mm}$ and packed into the three $0.04 \mathrm{~m}$ deep simulator trays shown in Fig. 1 as A, B and $\mathrm{C}$, to obtain near-field bulk density values. The device, whose cross section and plan views are presented in Fig. 1, had the following components: a $200 l$ supply tank, a water level recorder, a $1 \mathrm{~m}^{2}$ trays and buffer area, engine-driven electrical sump pump and hose connecting the supply tank to a sprinkler with a rotating disc set at a height of $1.5 \mathrm{~m}$ above the trays, associated valves, fittings and electrical wires, and wheels for simulator displacement. After packing the three soil sample repetitions in the trays, they were simultaneously irrigated by the fixed sprinkler delivering water at $40 \mathrm{kPa}$ and generating droplets with kinetic energy estimated as $17 \mathrm{~J} \mathrm{~kg}^{-1}$ by Kincaid (1996) method of calculation. The simulator buffer zone was used to mimic field surrounding the targeted soil area. While irrigating, samples of drainage (infiltrated) water were collected every $5 \mathrm{~min}$ from containers placed in the covered sumps numbered as 1, 2 and 3 (Fig. 1), at the same time as runoff and sediments were jointly collected from each individual tray collector opening. After accounting for runoff, each sample was oven dried and weighed to estimate sediment content. Treatment 1 , designed to emulate irrigation time and water application used in field sprinkler systems and to help predict soil behaviour under these circumstances, consisted of applying water to the soils at a rate of $67.8 \mathrm{~mm} \mathrm{~h}^{-1}$ for $30 \mathrm{~min}$. To replicate landscape and field characteristics commonly found in Southern Portugal, soil samples in the simulator trays were set 2.5 and $5 \%$
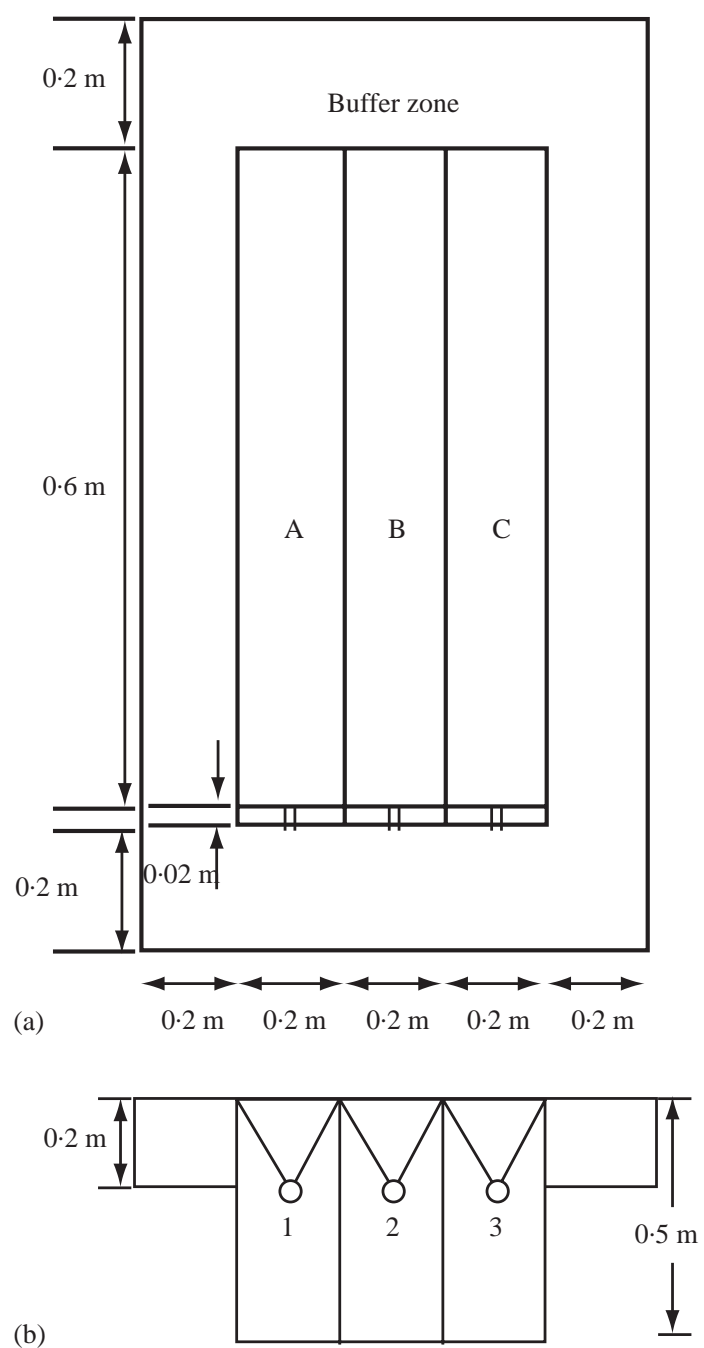

Fig. 1. Laboratory sprinkler simulator showing: (a) plan section view of the soil samples placement and packing trays $A, B, C$, and corresponding gutters for runoff collection; and (b) cross section view of the three trays drainage sampling outlets 1, 2 and 3 
slopes, respectively, to represent sub-treatments $1 \mathrm{~A}$ and 1B. All were irrigated three times for $30 \mathrm{~min}$ periods at weekly intervals. With a similar procedure, and time and amount of irrigation, the soil samples were subjected to treatment 2 , designed to apply $10 \mathrm{mg}^{-1}\left(1 \mathrm{~kg} \mathrm{ha}^{-1}\right)$ PAM with the first irrigation and test and predict its effectiveness when added to the soils through field sprinkler systems. As before, samples were prepared with slopes of 2.5 and $5 \%$ to represent sub-treatments $2 \mathrm{~A}$ and $2 \mathrm{~B}$, respectively. Application of PAM was followed by two PAM-free water irrigations. Also similar to treatment 1 , and to address the effects of time of application on soil infiltration, runoff and sediment loss, samples were collected every 5 min during the $30 \mathrm{~min}$ irrigation period. Besides emulating most frequently used field irrigation intervals, the weekly schedule promotes sequences of wet and dry conditions at the soil surface, described by Shainberg and Singer (1985) and Shainberg et al. (1991) as of relevant importance to the formation of a soil surface crust commonly observed in sprinkler irrigated fields. These conditions tend to often hinder infiltration and intensify runoff and sediment losses. All sub-treatments received tap water of $0.45 \mathrm{dS} \mathrm{m}^{-1}$ electrical conductivity and $\mathrm{pH}$ of 8.0. Polyacrylamide, injected into the irrigation line connecting the supply tank to the simulator sprinkler, was prepared to a concentration of $10 \mathrm{mg} \mathrm{l}^{-1}$ by mixing tap water with a commercially available water soluble high molecular weight anionic polymer (Superfloc A836 from CYTEC Industries Inc.).

\section{Results and discussion}

\subsection{Soil series cumulative infiltration, runoff and sediment loss}

\subsubsection{Irrigation effects on $2.5 \%$ gradient}

Figure 2(a) shows the cumulative infiltration obtained for each soil series. The plotted sequence, from left to right, shows soils with ever declining differences between the control (water-only applications) and PAM-added results. When compared to the control, applying PAM effectively increased infiltration on almost all soils. Figure 2(b) also shows the increasing effect of PAM in reducing soils runoff. Accordingly, even though showing low infiltration results when water-only irrigated, soil series Pmg, $\mathrm{Cb}, \mathrm{A} 1$ and $\mathrm{Pg}$ present the highest cumulative infiltration when PAM is added. For other soils, when compared to the control soil series Bpc, Vt, $\mathrm{Bp}$, Ppg and A2 infiltration results with PAM lag below the $6.8 \mathrm{~mm}$ overall recorded mean average difference, a fact that may have caused them to also show the lowest single differences in runoff among all soils. Worth
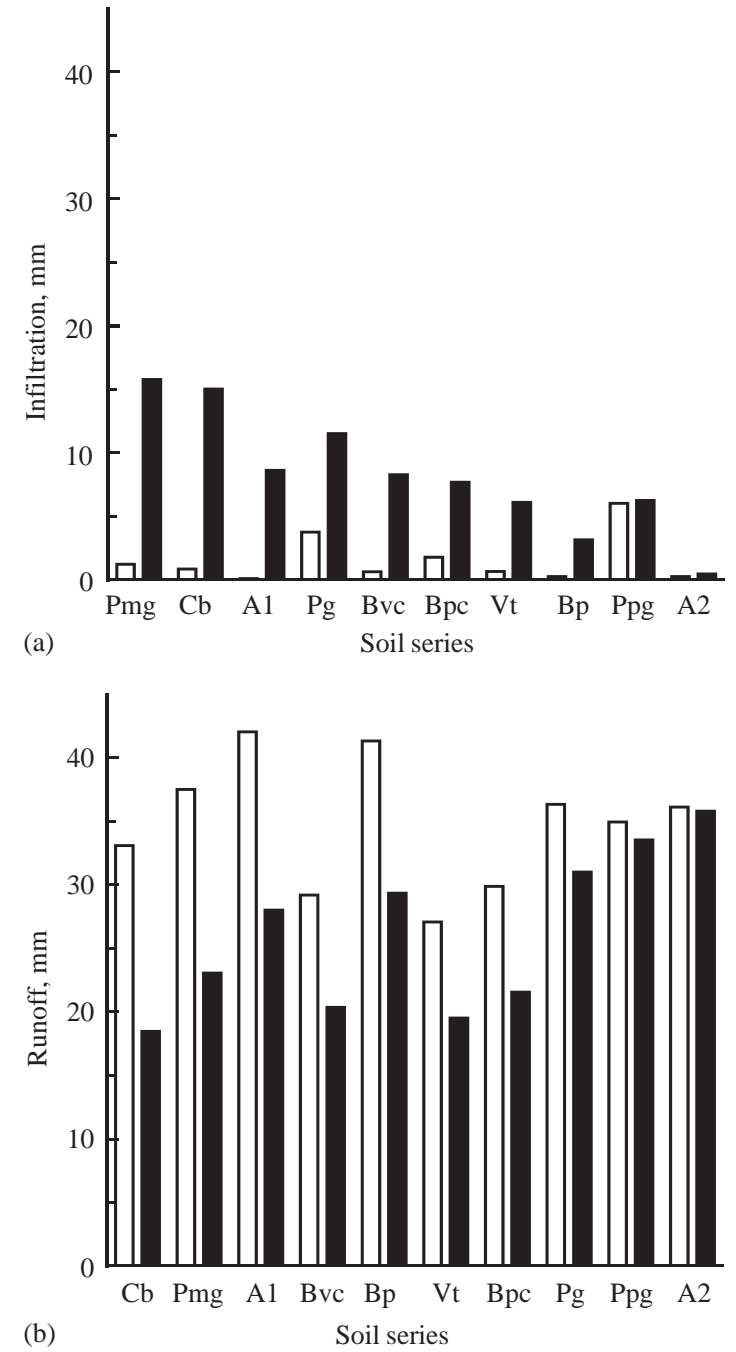

Fig. 2. Test of soil series (a) cumulative infiltration and (b) runoff measured during sprinkler simulator irrigation with $2.5 \%$ slope for two treatments: $\square$, control (water-only irrigations); $\mathbf{\square} 10 \mathrm{mgl}^{-1}$ polyacrylamide (PAM) applied with the first irrigation. Each soil was irrigated three times for 30 min periods at weekly intervals, with samples taken every 5 min during irrigation. Sequence plotted to show declining unit-soils infiltration and runoff differences between control and PAM treatments

noticing is that although soil series Ppg and A2 demonstrate a near nil response to PAM, the former shows the best infiltration performance among soils when water-only irrigated. To facilitate cross comparisons and rank performances, the results in Fig. 2 were broken down into the infiltration classes shown in Table 2. Except for soils A2 and Bp, all improved their infiltration with PAM application, showing soil series $\mathrm{Pmg}, \mathrm{Pg}$ and $\mathrm{Cb}$ the best infiltration recovery performances of all soils. According to Shainberg et al. (1991), and in the absence of enough sand particles to absorb energy, the mechanical impact of water droplets enhances clay dispersion and movement, inducing soil 
Table 2

Partition of ten soil series into infiltration classes; sediment samples were taken every $5 \mathrm{~min}$ during sprinkler simulator irrigation with $2.5 \%$ slope for two treatments: control (wateronly irrigations) and $10 \mathrm{mg} l^{-1}$ polyacrylamide (PAM) applied with the first irrigation. Soils were irrigated three times for $30 \mathrm{~min}$ periods at weekly intervals

\begin{tabular}{lll}
\hline $\begin{array}{l}\text { Infiltration } \\
\text { classes, } m m\end{array}$ & \multicolumn{2}{c}{ Partition of soil series, 2.5\% slope } \\
\cline { 2 - 3 } & \multicolumn{1}{c}{ Control } & \multicolumn{1}{c}{ PAM } \\
\hline $0-5$ & Vt; A2; A1; Pg; Pmg; & A2; Bp \\
& Bvc; Bpc; Cb; Bp & Vt; A1; Bvc; Bpc; \\
$5-10$ & Ppg & Ppg \\
& & Pg; Cb \\
$10-15$ & & Pmg \\
$15-20$ & & \\
\hline
\end{tabular}

pore blockage and crusting. This fact might explain the poor infiltration behaviour of Vertisols, even in the presence of PAM, particularly for the high clay plus silt content of soil series Bpc, Bvc and Bp (Table 1), and the unexpectedly high performance of soil series $\mathrm{Cb}$ that displays the highest sand and lowest silt plus clay size fraction percent among all Vertisols. Under the same assumption, the respectively 76.3 and $80.1 \%$ total sand and $26 \cdot 1$ and $22.4 \%$ silt plus clay reported for soil series Pmg and Pg might also explain for their higher performance with PAM, which seems to better bind to the coarser particles at the soil-water interface, increasing soils aggregate stability and infiltration.

Due to their poor infiltration potential, runoff was also relatively high on all soil series, especially for the low infiltration A1 and Bp soils. More in agreement with their good overall infiltration behaviour with PAM, considerably lower runoff was recorded for soil series Pmg and $\mathrm{Cb}$, resulting in respectively 80 and $60 \%$ runoff differences when compared to control. With an overall $40 \%$ average difference between control and PAM found for all soils, only three soil series, Pg, Ppg and A1, stayed below that line. Table 3 shows constructed runoff classes for the control and PAM-added treatments. Five of the soil series, Vt, Pmg, Cb, A1 and Bp, underwent soil surface changes with PAM that lowered their water-only runoff classes, suggesting that under field conditions treating irrigation water with polyacrylamide can be beneficial to soils.

Concerning sediment losses, Fig. 3 shows that when only water is applied to soils, unit $\mathrm{Cb}$ outperforms all, showing the lowest recorded sediment loss values. Soil series A1, A2 and Ppg displayed the highest sediment loss values. As seen before for infiltration, their high sand and low silt particle size fractions may explain the moderately low sediment loss values observed for soil series $\mathrm{Cb}$, Pmg, Pg and Vt. Alone, a high soil clay
Table 3

Partition of ten soil series into runoff classes; runoff samples were taken every 5 min during sprinkler simulator irrigation with $2.5 \%$ slope for two treatments: control (water-only irrigations) and $10 \mathrm{mg} l^{-1}$ polyacrylamide (PAM) applied with the first irrigation. Soils were irrigated three times for $30 \mathrm{~min}$ periods at weekly intervals

\begin{tabular}{llc}
\hline $\begin{array}{l}\text { Runoff } \\
\text { classes, } \mathrm{mm}\end{array}$ & \multicolumn{2}{c}{ Partition of soil series, $2 \cdot 5 \%$ slope } \\
\cline { 2 - 3 } & \multicolumn{1}{c}{ Control } & \multicolumn{1}{c}{ PAM } \\
\hline $0-20$ & $\mathrm{Vt} ; \mathrm{Bvc}$; Bpc & Vt; Cb \\
$20-30$ & & A1; Pmg; Bvc; \\
& A2; Pg; Pmg; Ppg; Cb & A2; Pg; Ppg \\
$30-40$ & A1; Bp & \\
$40-50$ & & \\
\hline
\end{tabular}

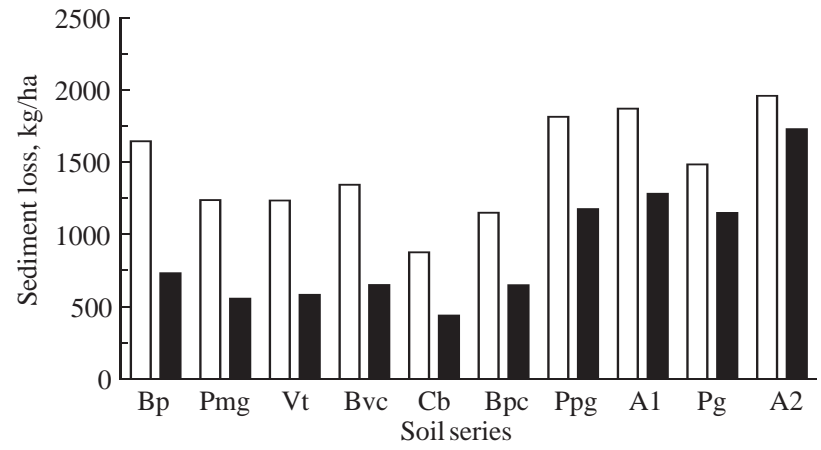

Fig. 3. Test of soil series sediment loss measured during sprinkler simulator irrigation with $2.5 \%$ slope for two treatments: $\square$, control (water-only irrigations); $\mathbf{\square}, 10 \mathrm{mgl}^{-1}$ polyacrylamide (PAM) applied with the first irrigation. Each soil was irrigated three times for 30 min periods at weekly intervals, with samples taken every 5 min during irrigation. Sequence plotted to show declining unit-soils sediment loss differences between control and PAM treatments

content seems to play a more moderate role than sand in reducing sediment loss, as suggested by the high clay losses from soils $\mathrm{Bvc}$ and $\mathrm{Bpc}$ losses, and the disappointingly high losses recorded for the soil Bp. Concerning PAM application, the sequencing technique used for Fig. 2 was repeated here for Fig. 3, where the ever declining sediment loss differences, plotted from left to right, show that all soil series positively responded to PAM treatment. Soil series Bp and A1, which already had curtailed their runoff with PAM show here also to considerably reduce their sediment losses with the application of PAM. As the sediment loss class distributions of Table 4 show, the five soil series, Vt, $\mathrm{Pmg}, \mathrm{Cb}, \mathrm{A} 1$ and $\mathrm{Bp}$, giving lower runoff classes with PAM, also gave lower sediment loss, with percent difference improvements as high as $100 \%$ observed for soil series $\mathrm{Bp}, \mathrm{Pmg}, \mathrm{Vt}, \mathrm{Bvc}$ and $\mathrm{Cb}$. With their result differences staying below the overall soils $79 \%$ average 
Table 4

Partition of ten soil series into sediment loss classes; sediment samples were taken every $5 \mathrm{~min}$ during sprinkler simulator irrigation with $2.5 \%$ slope for two treatments: control (wateronly irrigations) and $10 \mathrm{mg} l^{-1}$ polyacrylamide (PAM) applied with the first irrigation. Soils were irrigated three times for $30 \mathrm{~min}$ periods at weekly intervals

\begin{tabular}{|c|c|c|}
\hline \multirow{2}{*}{$\begin{array}{l}\text { Sediment loss } \\
\text { classes, } \mathrm{kg} \mathrm{ha}^{-1}\end{array}$} & \multicolumn{2}{|c|}{ Partition of soil series, $2.5 \%$ slope } \\
\hline & Control & $P A M$ \\
\hline $500-1000$ & $\mathrm{Cb}$ & $\begin{array}{l}\text { Vt; Pmg; Bvc; Bpc; } \\
\text { Cb; Bp }\end{array}$ \\
\hline $1000-1500$ & $\begin{array}{l}\text { Vt; Pg; Pmg; Bvc; } \\
\text { Bpc }\end{array}$ & $\mathrm{A} 1 ; \mathrm{Pg} ; \mathrm{Ppg}$ \\
\hline $1500-2000$ & A2; A1; Ppg; Bp & $\mathrm{A} 2$ \\
\hline
\end{tabular}

sediment loss difference observed between the control and PAM treatments, soil series Pg, Ppg, A1 and A2 also show, nevertheless, considerable sediment loss reductions with PAM. More modest results were observed for soil series Pg and A2. As corroborated by the infiltration and runoff results, the overall reported sediment loss values seem also to suggest that under field conditions PAM application may positively contribute to the reduction of the observed sediment losses induced by sprinkler irrigation.

\subsubsection{Irrigation effects on $5 \%$ gradient}

Figure 4(a) shows cumulative infiltration obtained for each unit-soil. Overall, increasing the slope to $5 \%$ slightly decreased soils cumulative infiltration and did not substantially change their already described low water-only irrigation infiltration characteristics. Unexpectedly, applying PAM with the first irrigation increased infiltration on all soils by $24 \%$ when compared to $2.5 \%$ slope. This fact had an impact on runoff values, with PAM-treated soils showing only a marginal $10 \%$ average runoff increase with the increased slope. As observed in Fig. 4, and despite the slope increase, soil series Pmg and $\mathrm{Cb}$ responses to PAM continued to be high, with substantial increases in infiltration, 15.7 and $15.8 \%$, and reduction in runoff, 59.4 and $82.7 \%$ respectively, when compared to control. Only soil series A2 and Bp continued unresponsive to PAM application, as they did when exposed to the $2.5 \%$ slope. As for sediment losses, Fig. 5 shows that, when exposed to the $5 \%$ slope and water-only applied irrigation, the general behaviour of soils did not change dramatically relative to Fig. 3. Except for soil series Vt and Bpc, all soils increased the sediment loss, with the highest increase differences observed for soil series $\mathrm{Pg}$, $\mathrm{Bvc}$ and Bp. Soils were more responsive to PAM application, with soil Pmg showing the largest sediment reduction with slope increase, followed by $\mathrm{Bpc}$ and $\mathrm{Cb}$
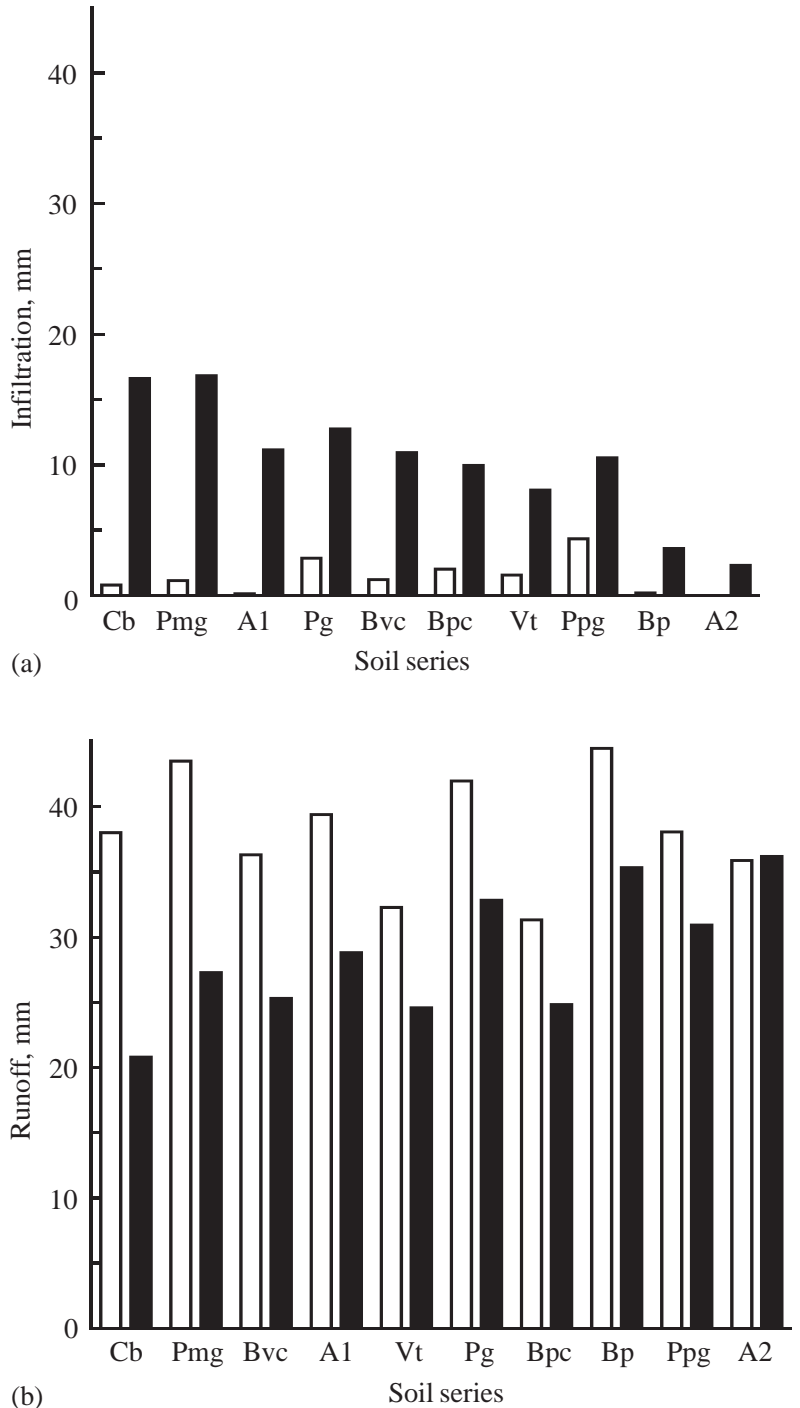

(b)

Fig. 4. Test of soil series (a) cumulative infiltration and (b) runoff measured during sprinkler simulator irrigation with 5\% slope for two treatments: $\square$, control (water-only irrigations); 口, $10 \mathrm{mgl}^{-1}$ polyacrylamide (PAM) applied with the first irrigation. Each soil was irrigated three times for 30 min periods at weekly intervals, with samples taken every 5 min during irrigation. Sequence plotted to show declining unit-soils infiltration and runoff differences between control and PAM treatments

soils. Soil series Bvc, Ppg and Bp, which had the worst record with water-only irrigation, were also very responsive to PAM. Table 5 presents soil series class distributions for sediment loss when water-only and PAM irrigations are used. Compared to Table 4, it is worth noticing that slope increase imposed one more class to Table 5, 2000 to $2500 \mathrm{~kg} \mathrm{ha}^{-1}$, and different class distributions for the soil series. Table 6 shows PAM-treated soil series whose infiltration, runoff and sediment loss results were significantly different from control (probability $P<0 \cdot 05$ ). 
Table 7 shows aggregate soil infiltration, runoff and sediment loss obtained for treatments 1 and 2 (wateronly and PAM-added) for the two slopes. In general,

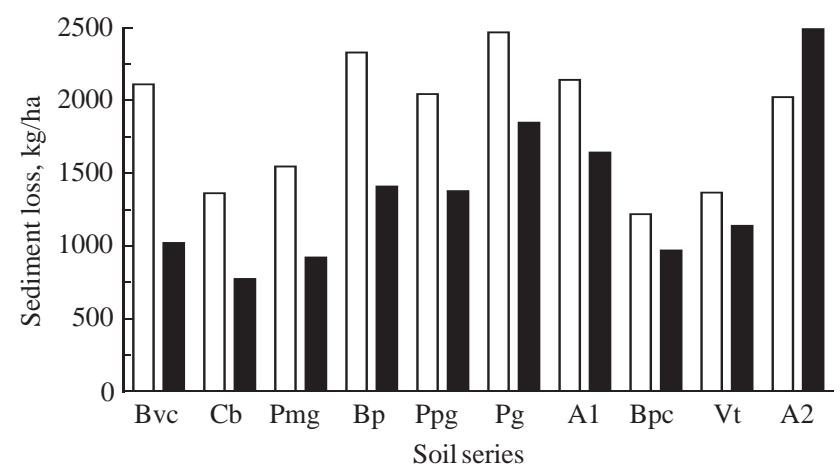

Fig. 5. Test of soil series sediment loss measured during sprinkler simulator irrigation with 5\% slope for two treatments: $\square$, control (water-only irrigations); $\square, 10 \mathrm{mg} \mathrm{l}^{-1}$ polyacrylamide (PAM) applied with the first irrigation. Each soil was irrigated three times for 30 min periods at weekly intervals, with samples taken every 5 min during irrigation. Sequence plotted to show declining unit-soils sediment loss differences between control and PAM treatments

Table 5

Partition of ten soil series into sediment loss classes; sediment samples were taken every $5 \mathrm{~min}$ during sprinkler simulator irrigation with 5\% slope for two treatments: control (water-only irrigations) and $10 \mathrm{mg} l^{-1}$ polyacrylamide (PAM) applied with the first irrigation. Soils were irrigated three times for $30 \mathrm{~min}$ periods at weekly intervals

\begin{tabular}{lll}
\hline $\begin{array}{l}\text { Sediment } \\
\text { loss classes, } \\
k g h a^{-1}\end{array}$ & \multicolumn{1}{c}{ Partition of soil series, 5\% slope } \\
\cline { 2 - 3 } & \multicolumn{1}{c}{ Control } & \multicolumn{1}{c}{ PAM } \\
\hline $500-1000$ & & Pmg; Bpc; Cb \\
$1000-1500$ & Vt; Bpc; Cb & Vt; Bvc; Ppg; Bp \\
$1500-2000$ & Pmg & A1; Pg \\
$2000-2500$ & A2; A1; Pg; Bvc; & A2 \\
& Ppg; Bp & \\
\hline
\end{tabular}

and for water-only applied irrigation soils, as slope increases to $5 \%$, infiltration decreases by $7 \%$ and runoff and sediment loss increase by 9 and $27 \%$, respectively. These figures seem to corroborate indications, supported also by Santos et al. (2001) for more than 20 centre-pivot irrigation, that in the undulating and fragile landscape of Southern Portugal the intensive use of sprinklers can impose serious environmental risks on irrigated soils. Exposure to a 5\% slope unexpectedly boosted the infiltration of already PAM-treated soils to a $24 \%$ difference and increased runoff by only $10 \%$. It had, however, a less positive effect on sediment loss, the slope change causing an overall sediment increase of $52 \%$. Although PAM proved very beneficial in enhancing soils overall infiltration, as slope increases PAM application does not seem effective in controlling runoff and sediment losses. Nevertheless, PAM increased overall soil series infiltration by 457 and $642 \%$ on 2.5 and $5 \%$ slopes, respectively, reduced runoff by $25 \%$ on both accounts and lessened sediment losses by 39 and $27 \%$ when compared to water-only irrigations. These facts, corroborated also by the results of Santos et al. (2001) for more than 20 monitored center-pivot field irrigation on Pmg and A1 soil series seem to indicate that small amounts of PAM applied to the soils through the irrigation water may have the potential to moderate the environmental risks associated with the use of sprinkler irrigation systems in Southern Portugal. Table 8 shows PAM-treated and control soil series infiltration, runoff and sediment loss results that were significantly different $(P<0.05)$ when exposed to the slope increase.

\subsection{Time of irrigation and infiltration, runoff and sediment loss}

\subsubsection{Irrigation effects on $2 \cdot 5 \%$ gradient}

Aggregated results of all soil infiltration data collected every $5 \mathrm{~min}$ during the three water-only sprinkler

Table 6

Significant effects of $10 \mathrm{mg} l^{-1}$ polyacrylamide (PAM) applied with the first irrigation and control (water-only irrigations) treatments on soil series infiltration, runoff and sediment loss under 2.5 and $5 \%$ slopes. Treatment differences calculated by simple ANOVA with probability $P<0 \cdot 05$

\begin{tabular}{|c|c|c|c|c|c|c|}
\hline \multirow{4}{*}{ Improvement by $P A M$} & \multicolumn{6}{|c|}{ Soil series } \\
\hline & \multicolumn{2}{|c|}{ Infiltration } & \multicolumn{2}{|c|}{ Runoff } & \multicolumn{2}{|c|}{ Sediment loss } \\
\hline & \multicolumn{2}{|c|}{ Slope, \% } & \multicolumn{2}{|c|}{ Slope, $\%$} & \multicolumn{2}{|c|}{ Slope, \% } \\
\hline & 2.5 & $5 \cdot 0$ & 2.5 & $5 \cdot 0$ & 2.5 & $5 \cdot 0$ \\
\hline$P<0 \cdot 05$ & $\begin{array}{l}\mathrm{A} 1, \mathrm{Pg}, \\
\mathrm{Pmg}, \\
\mathrm{Bpc}, \mathrm{Bvc}, \\
\mathrm{Cb}\end{array}$ & $\begin{array}{l}\text { A1, A2, Pg, } \\
\text { Pmg, Ppg, } \\
\text { Bpc, Bvc, } \\
\text { Cb }\end{array}$ & $\mathrm{Cb}$ & $\mathrm{Cb}$ & $\begin{array}{l}\text { Ppg, Bp, } \\
\mathrm{Cb}\end{array}$ & $\mathrm{Ppg}, \mathrm{Cb}$ \\
\hline
\end{tabular}


Table 7

Total soil series cumulative infiltration, runoff and sediment loss of samples taken every 5 min during sprinkler simulator irrigation with $2.5 \%$ and $5 \%$ slopes for two treatments: control (water-only irrigations) and $10 \mathrm{mg} l^{-1}$ polyacrylamide (PAM) applied with the first irrigation. Soils were irrigated three times for $30 \mathrm{~min}$ periods at weekly intervals

\begin{tabular}{|c|c|c|c|c|c|c|}
\hline \multirow[t]{3}{*}{ Treatment } & \multicolumn{2}{|c|}{ Total infiltration, $\mathrm{mm}$} & \multicolumn{2}{|c|}{ Total runoff, mm } & \multicolumn{2}{|c|}{ Total sediment loss, $\mathrm{kgha}^{-1}$} \\
\hline & \multicolumn{2}{|c|}{ Slope } & \multicolumn{2}{|c|}{ Slope } & \multicolumn{2}{|c|}{ Slope } \\
\hline & $2 \cdot 5 \%$ & $5 \%$ & $2 \cdot 5 \%$ & $5 \%$ & $2 \cdot 5 \%$ & $5 \%$ \\
\hline Control & $14 \cdot 9$ & $13 \cdot 8$ & $347 \cdot 7$ & $381 \cdot 1$ & $14610 \cdot 6$ & $18614 \cdot 4$ \\
\hline PAM & $82 \cdot 8$ & $102 \cdot 5$ & $260 \cdot 8$ & $286 \cdot 8$ & $8922 \cdot 0$ & $13560 \cdot 1$ \\
\hline
\end{tabular}

Table 8

Significant effects of 2.5 and $5 \%$ slopes observed on soil series infiltration, runoff and sediment loss under $10 \mathrm{mg} l^{-1}$ polyacrylamide (PAM) applied with the first irrigation and control (water-only irrigations) treatments. Treatment differences calculated by simple ANOVA with probability $P<0.05$

\begin{tabular}{|c|c|c|c|c|c|c|}
\hline \multirow[t]{4}{*}{$2.5 \%$ and $5 \%$ slope } & \multicolumn{6}{|c|}{ Soil series } \\
\hline & \multicolumn{2}{|c|}{ Infiltration } & \multicolumn{2}{|c|}{ Runoff } & \multicolumn{2}{|c|}{ Sediment loss } \\
\hline & \multicolumn{2}{|c|}{ Treatment } & \multicolumn{2}{|c|}{ Treatment } & \multicolumn{2}{|c|}{ Treatment } \\
\hline & Control & $P A M$ & Control & $P A M$ & Control & $P A M$ \\
\hline$P<0.05$ & - & A2 & - & - & $\mathrm{Pg}, \mathrm{Cb}$ & - \\
\hline
\end{tabular}

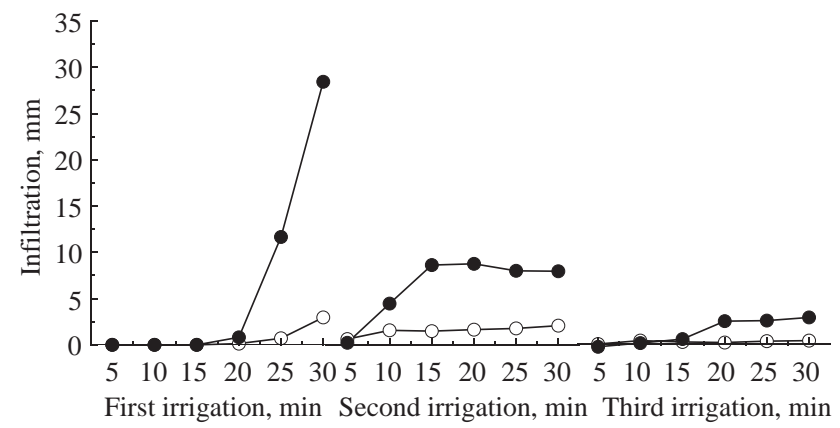

Fig. 6. Test of soil series cumulative infiltration over time measured during sprinkler simulator irrigation with $2.5 \%$ slope for two treatments: $\bigcirc$, control (water-only irrigations), $10 \mathrm{mg} \mathrm{l}^{-1}$ polyacrylamide (PAM) applied with the first irrigation. Each soil was irrigated three times for 30 min periods at weekly intervals, with samples taken every 5 min during irrigation

simulator irrigations (Fig. 6) show a very slight rise in the aggregate soil infiltration rate with time. These findings cast some doubts on the merits of the frequently used practice of managing moving sprinkler irrigation systems on these low infiltration rate soils by increasing their speed, expecting water application to approach, or match, the soil infiltration rate. Moreover, as the speed is increased more machine turns are required to adequately irrigate the field before crop water needs are satisfied, making the procedure costly and time consuming. Alternatively, and as suggested by the high rise in the infiltration results shown in Fig. 6, farmers

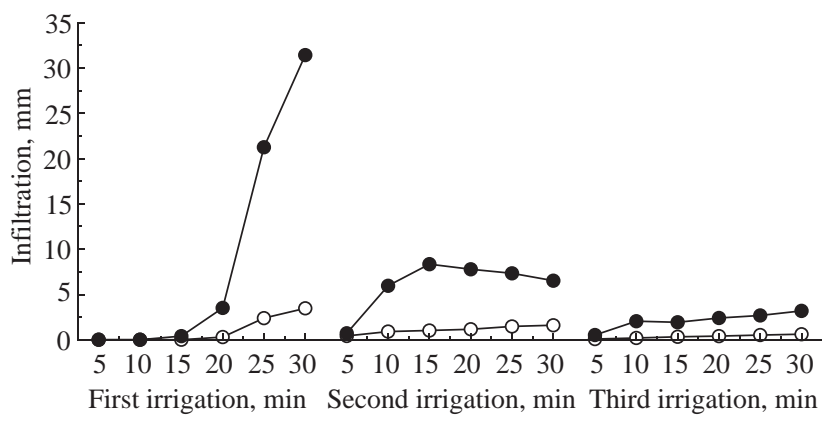

Fig. 7. Test of soil series cumulative infiltration over time measured during sprinkler simulator irrigations with 5\% slope for two treatments: $\bigcirc$, control (water-only irrigations); $\mathbf{0}$, $10 \mathrm{mg} \mathrm{l}^{-1}$ polyacrylamide (PAM) applied with the first irrigation. Each soil was irrigated three times for 30 min periods at weekly intervals, with samples taken every 5 min during irrigation

will be better off applying PAM to enhance the soil infiltration rates. Rapidly increasing water-only irrigation runoff and sediment losses with time (data not shown) and more moderately increasing rates with PAM also reinforce the benefits of using such an alternative to manage sprinkler irrigation in Southern Portugal.

\subsubsection{Irrigation effects on $5 \%$ gradient}

Aggregated results of all soil infiltration data collected every $5 \mathrm{~min}$ during the three water-only and PAM irrigation periods (Fig. 7) indicate that the increase in slope did not alter the pattern of results already 
presented in Fig. 6. A slight rise in the water-only soil infiltration was observed since the beginning of the first irrigation, from $0.0 \mathrm{~mm}$ to $2.5 \mathrm{~mm}$, and to a maximum of $4 \mathrm{~mm}, 25$ minutes into the irrigation, whereas PAM increased soil infiltration form 0.0 to $22 \mathrm{~mm}$, and to a maximum of $33 \mathrm{~mm}$. For both treatments, infiltration stayed practically unchanged for the second and third irrigation periods, closely following the $2.5 \%$ slope pattern shown in Fig. 6. As expected, results also show that slope increase worsened runoff and sediment loss values since the beginning of irrigations (data not presented). Polyacrylamide was better able to cope with the greater slope and enhanced infiltration throughout the irrigation period, a fact more apparent on the first irrigation. The worsening of water-only irrigation results with the increase in slope also do not support the currently used practice of faster machine turns to manage infiltration and curb runoff and sediment losses in rolling landscapes. Application of PAM seems a better alternative to carry out such desiderata.

\section{Conclusions}

Sprinkler irrigation simulation tests conducted in the laboratory to evaluate and assess the impacts of sprinkler irrigation on ten representative soil series of Southern Portugal proved to be a robust, practical and cost-effective method, and a viable alternative, to field data collection. They show that the intensive use of sprinklers in the rolling and fragile landscape may impose serious environmental risks to the irrigated soils. By controlling soil infiltration, runoff and sediment loss, small amounts of PAM seem to be able to moderate such risks in selected soils. Such ability of PAM will allow for improvement on the currently inefficient, labour-intensive and costly management practice of increasing the speed of moving sprinklers to match their water application to the ever falling soil infiltration rates. Applying PAM with the first irrigation water to a concentration of $10 \mathrm{mg}^{-1}$ minimised these shortcomings and may provide for longer irrigation set times, higher application rates and improved irrigation efficiencies. The ability of PAM to influence surface soil conditions and enhance infiltration also supports its use, paired, or as a viable alternative, to building reservoir basins in-between ridges, a practical but more costly and time consuming soil conservation practice.

\section{Acknowledgements}

This work was partially funded through INIA/Agro \#14/Medida 8/Acção 8.1 and supported by FRH/FCT/
MCES. The authors would also like to acknowledge the support of Profs. Alfredo Gonçalves Ferreira and José Rafael Silva, and the dedicate work of Eng. João Roma and laboratory technicians Mrs. Manuel Junça, Custódio Alves and Beatriz Castor.

\section{References}

Aase J K; Bjorneberg D L; Sojka R E (1998). Sprinkler irrigation runoff and erosion control with polyacrylamide-laboratory tests. Soil Science Society of America Journal, 62, 1681-1687

Bjorneberg D L; Aase J K (2000). Multiple polyacrylamide applications for controlling sprinkler irrigation runoff and erosion. Applied Engineering in Agriculture, 16(5), 501-504

CNROA (1987). Representatividade das famílias de solos presentes nos distritos de Évora, Beja e Setúbal. [Representativity of existing soil families in the district of Evora, Beja and Setubal.] Centro Nacional de Reconhecimento e Ordenamento Agrário, Lisboa

Cardoso C J V J (1965). Os solos de Portugal. Sua classificação, caracterização e génese. 1-A sul do rio Tejo. [Soils of Portugal. Classification, characterization and genesis. 1-south of Tagus river.] Secretaria de Estado da Agricultura, Direcção-Geral dos Serviços Agrícolas, Lisboa

Ferreira A G; Alexandre C; Cassamá S (1994). Effect of soil conditioners on the infiltration rate of an alluvial soil. In: Conserving Soil Resources, European Perspectives (Rickson R J, ed), pp 30-35. Cab International

Hasheminia S M (1994). Controlling runoff under low pressure center pivot irrigation systems. Irrigation and Drainage Systems, 8, 25-34

INE (2001). Recenseamento Geral da Agricultura, 1999: Alentejo, Principais Resultados. [General agriculture survey, 1999: Alentejo, main results.] Instituto Nacional de Estatística, Lisboa

Kincaid D C (1996). Spray drop kinetic energy from irrigation sprinklers. Transactions of the ASAE, 39(3), 847-853

Kincaid D C; McCann I; Busch R J; Hasheminiam M (1990). Low pressure center pivot irrigation and reservoir tillage. In: Visions of the Future. Proceedings of the ASAE Third National Irrigation Symposium, pp 54-60. Phoenix, Arizona

Morin J; Goldberg D; Seginer I (1967). A rainfall simulator with a rotating disk. Transactions of the ASAE, 10, 74-79

Santos F L; Martins O C; Castanheira N S; Figueiredo C (2001). Center pivot sprinkler irrigation, runoff and erosion control in a Mediterranean soil with polyacrylamide. ASAE Paper No. 012155

Santos F L; Serralheiro R P (2000). Improving infiltration of irrigated Mediterranean soils with polyacrylamide. Journal of Agricultural Engineering Research, 76, 83-90

Santos F L; Serralheiro R P; Melhorado F S; Oliveira M R (1998). Control of furrow erosion and infiltration on a Mediterranean soil using polyacrylamide. In: Water and the Environment: Innovative Issues in Irrigation and Drainage (Pereira L S; Gowing J, eds), pp 84-91. E \& FN Spon, London

Serralheiro R; Bettencour A; Carvalho J M; Fernandes J P; Pinto P (1997). Recursos Hídricos do Alentejo. Perspectiva de utilização duradoura. [Water resources of Alentejo. Perspectives on its sustainable use.] Publicações Universidade de Évora, série Ciências da Natureza e Ambiente No 1 
Shainberg I; Gal M; Ferreira A G; Goldstein D (1991). Effect of water quality and amendments on the hydraulic properties and erosion from several Mediterranean soils. Soil Technology, 4, 135-146

Shainberg I; Singer M J (1985). Effects of electrolyte concentration on the hydraulic properties of depositional crust. Soil Science Society of America Journal, 49, $1260-1263$

Silva J R M (1999). Susceptibilidade do solo à erosão hídrica:avanço na modelação. [Soil susceptibility to water induced erosion: advances in modelling.] PhD Dissertation, University of Evora, Evora, Portugal

Slack D C; Larson C L (1981). Modelling infiltration: the key process in water management, runoff and erosion. In:
Tropical Agricultural Hydrology (Lal R; Russell E W, eds). John Wiley and Sons Ltd, New York

Sojka R E; Lentz R D; Ross C W; Trout T J; Bjorneberg D L; Aase J K (1998). Polyacrylamide effects on infiltration in irrigated agriculture. Journal of Soil and Water Conservation, 53 (4), 325-331

Sojka R E; Lentz R D; Shainberg I; Trout T J; Ross C W; Robbins C W; Entry J A; Aase J K; Bjorneberg D L; Orts W J; Westermann D T; Morishita D W; Watwood M E; Spofford T L; Barvenik F W (2001). Irrigating with polyacrylamide (PAM) - nine years and a million acres of experience. Proceedings of the 4th Decennial Symposium: National Irrigation Symposium, pp 161-169. ASAE publication No. 701P0004 